\title{
Framing Referendum Campaigns: the 2014 Scottish Independence Referendum
}

in the Press.

\section{Marina Dekavalla, University of Stirling}

\begin{abstract}
This article explores the framing of referendum campaigns in the press and its relationship to the framing of elections. Drawing from an empirical analysis of the newspaper coverage of the 2014 Scottish referendum and from previous research on campaigns in different contexts, it finds that frames associated with elections, like the 'strategic game' and policy frames, were also dominant in the framing of the referendum. It argues that by framing the independence debate in similar terms to other political contests, the press promoted an understanding of this event as being about pragmatic decision-making on policy and political competition, rather than purely a decision about constitutional matters of self-determination.
\end{abstract}

Keywords: Referendum, framing, content analysis, newspapers, Scotland, media coverage.

Referendums are different political events from elections: they are not competitions between political parties to come into power but essentially consultations of the electorate on a divisive issue that goes beyond the lifespan of individual governments; they are one-offs, not regular events; there is not always clear correspondence between party identification and ideological stance and parties with diverse ideologies may support the same side (de Vreese and Semetko, 2004a). 
Although research on news coverage of election campaigns has been ongoing since the 1940s (Patterson, 1980), the coverage of referendums in the news is comparatively an under-researched area (de Vreese and Semetko, 2004b: 714). This article uses frame analysis, a method that has made a substantial contribution to our understanding of election coverage, to look at the way the 2014 Scottish referendum on independence from the United Kingdom was represented in a range of Scottish newspapers. Drawing from the analysis of the specific case and reflecting on previous studies of campaigns on other topics and national contexts, it addresses the following question: did the press coverage of the referendum generate different frames compared to those of election campaigns, as would be justified by the different nature of these political events? The findings have implications both for our understanding of referendums as mediated events and for evaluating the performance of the news media in explaining what a referendum is about.

This latter is particularly significant because the media are for most people a key source of information on politics, and how they define referendums matters (Wettstein, 2012). Despite the dramatic decline of the print press internationally and in Scotland specifically (Dekavalla, 2015), it remains a significant part of the 'relay race' of discourses in the public sphere (Garton et al., 1991: 100-103), whereby print, broadcast and online media co-create the mediated public debate and re-represent political discourse on different platforms. The 2014 referendum has been hailed as an occasion where grassroots groups reinvigorated the debate on social media and challenged the dominance of traditional news platforms (Law, 2015), but these accounts also recognize that the press and broadcasting remained important 'in setting the parameters of official political discourse as well as registering the ways in which 
social media replicate the established patterns of political discourse as much as it threatens to dislodge them' (ibid: 7). Newspapers may have had a relatively restricted print readership, but they were read by political elites and by contributors to broadcast and online media, they often became themselves direct or indirect contributors to online conversations, while the material dominating the debate on 'old' media was also the main material for discussion on social media (Paterson, 2015: 23). For this reason newspapers are worth studying, as they remain a component of this multiplatform debate. A discussion, however, of how newspaper coverage was interpreted and used by other parts of the public sphere, or by voters in their decisionmaking process, would require a wider range of data, and the influence of the coverage on the outcome of the referendum falls outside the scope of this article.

I begin with a brief summary of the history of the Scottish constitutional issue and the role of the press in the Scottish polity. I then introduce framing as an analytical approach, particularly in relation to its applications in the study of elections, and explain the methodology and data sets used in this analysis. Following this, I present the frames identified in the newspaper coverage and discuss their overall prominence in the sample, as well as in individual newspapers. Finally, I discuss possible explanations and implications of these findings.

\section{The constitutional issue}

The issue of Scottish independence was not new in 2014. Scotland has historically been described as a 'stateless nation' (McCrone, 2001) within the UK state, namely a people sharing culture and history, without the political authority over a territory and 
'internal uniformity of rule' (Guibernau and Goldblatt, 2000:124) that additionally characterise nation-states. Nation-states are widely seen as sociological constructs, which developed in their current form during the emergence of capitalism in Europe (Anderson, 1983; Balibar, 1991). Scottish nationalism though grew in the $20^{\text {th }}$ century when, according to Nairn (1977), the financial benefits of the union with the rest of the UK began to decrease. For this reason he suggests that Scotland's discourse of nationalism has been political rather than cultural (ibid).

In its early years in the 1930s-1950s, the main promulgator of Scottish independence, the Scottish National Party (SNP) attracted marginal support (Devine, 1999). As Britain progressively lost its colonial power though, and manufacturing started to decline, the nationalist cause gained ground, further bolstered by the discovery of oil in the North Sea between 1969-1971. The post-war period also saw a loosening of traditional understandings of Britishness, which is often attributed to the collapse of the Empire, the gradual distancing of Scotland, Wales and Northern Ireland, the multiculturalism resulting from immigration and the rise of the European Union (Kumar, 2003). Both economic and cultural factors were hence becoming more conducive for increased autonomy of the UK nations.

The success of the SNP in securing a small but important share of parliamentary seats in the late 1960s brought the Scottish constitutional issue into mainstream political debate as the party's larger political opponents, concerned about the SNP's growth and the possibility of a potential dissolution of the British union, began to consider the idea of devolution (Schlesinger et al., 2001). The first Scottish referendum on devolution in 1979 failed to secure the support of the then required 
$40 \%$ of the electorate. However in the two following decades, increasing dissatisfaction among Scots with consecutive Conservative administrations' economic and social policies further widened the gap between political agendas in Scotland and in England (Devine, 1999; Schlesinger et al., 2001). In the late 1980s - early 1990s, a stronger devolution movement emerged, compared to that of the 1970s, with the support of several parties and civil society actors. Labour's 1997 election victory instigated the second Scottish referendum on devolution later in the same year, which resulted in the devolution of powers on matters affecting daily life in the region from Westminster to a parliament located in Scotland.

The third referendum, on 18 September 2014, was the first one specifically on independence and took place in a different political context: the devolved Scottish Parliament was in its fourth session; the SNP, which proposed the referendum, had been in power for the last eight years, taking over from Labour as the most popular party in Scotland; the Conservative party, traditionally unpopular north of the Scottish border, had returned to power in Westminster in a coalition which promoted economic austerity; disengagement with Westminster politics in Scotland was reinforced both by the economic and welfare policies adopted by the coalition and by the management of the banking crisis, the Iraq war, and the expenses scandal under previous Labour administrations - there was therefore growing Scottish disillusionment with all the major Westminster parties; the EU, once a cross-national alliance promising security for smaller states (Dardanelli, 2005), had been in severe financial crisis for the previous six years. 
Although support for the SNP grew in the post-devolution years to the extent that in 2011 it won a majority in the Scottish Parliament, its rhetoric in elections did not emphasize independence but policy (McNair, 2008). Independence did not gain majority support during these years: surveys early in the referendum campaign showed similar levels of support for independence, increased devolution and the status quo, while increased devolution was the 'least opposed' option (Curtice, 2014). However, Paterson (2015) suggests that the post-devolution years may be seen as part of a recurring process in the Union's history: he argues that Scotland historically has not been content in the Union because it felt it was treated unequally in policy terms; this led to political pressure for change, which in turn made London agree to cede some power in order to keep the Union together; but this was just a compromise, which kept pressure forces happy for a short time, but eventually led to frustration and pressure for more change. Hence, behind the pressure for independence lay a perception that there was a political, social and ideological gap between Scotland and Westminster.

The SNP was the biggest party in the official Yes campaign (which also included the Scottish Green Party and the Scottish Socialist Party), while the Scottish Labour, Conservative and Liberal Democrat parties supported the No side (Better Together). The Yes campaign encouraged and nurtured the development of a substantial grassroots movement, which is seen as having galvanized the campaign beyond what the political parties in Yes Scotland could have on their own (Paterson, 2015). The involvement of grassroots campaigners arguably pushed both official campaigns towards a more direct engagement with voters than is usual in political campaigning. 
The long history of the Scottish constitutional debate means that discourses on constitutional change pre-existed in the public sphere: for example the sense of a distinctive Scottish identity and history, or the perceived need for Scotland to determine its own affairs had been part of political discourse in previous referendums (Denver, 2002). Previous research on referendums has found that when voters are familiar with the topic of a referendum, little volatility is to be expected (LeDuc, 2002: 157-8). In this case though, the long campaign saw both an increase in awareness of the event among the electorate $(84.6 \%$ of those registered voted, an unprecedented turnout in any UK election or referendum) and a narrowing of what was originally a large gap between the two sides (Barford, 2014). Eventually voters decided that Scotland should stay in the UK (with 55\% support for No).

\section{The Scottish Press}

Scottish newspapers have traditionally held a special role in the life of the nation. Many scholars (Smith, 1994; Schlesinger, 1998; Connell, 2003) see the press in Scotland as serving and helping to maintain a separate civil society and public sphere throughout the three centuries of its union with England. Together with the Scottish legal and judicial systems, the Church of Scotland and the Scottish education system, newspapers have been an institution that kept the Scottish public sphere distinctive for much of its history (McNair, 2008).

The major indigenous Scottish titles, some of them established in the $18^{\text {th }}$ and $19^{\text {th }}$ centuries, increasingly faced competition from Scottish editions of London titles in the decades leading up to the referendum. As Hutchison (2008: 66-68) suggests, the 
political changes that took place since the 1970s and are briefly outlined above were not accompanied by an increased loyalty towards the indigenous press; instead these years saw a strengthening of the position of London titles, which eroded indigenous newspapers' circulations with products that specifically targeted the Scottish market. In addition to this, by the time of the referendum the Scottish press was also facing sustainability problems as part of a global trend of competition with newer media platforms for readership and advertising (Dekavalla, 2015).

Scottish newspapers though remained important sources for news on Scottish politics (together with Scottish broadcasting), despite their emphasis on 'low-level scandals, corruption and mediocrity' when reporting on the early years of the devolved parliament (McNair, 2008: 234), as Scottish stories became even more scarce in media outside the region post-devolution. Within the context of the broader readership decline they were experiencing, Scottish newspaper editors saw in the 2014 referendum an opportunity to reaffirm their challenged relationship with Scottish readers, because they saw themselves as one of few platforms for discussion on Scottish affairs (Dekavalla, 2015).

This recognition of the significance of the referendum was not accompanied by support for independence. Although most Scottish newspapers supported devolution in the 1997 referendum, they remained pro-Union and sceptical of independence in subsequent years - even those that supported the SNP in individual elections were keen to 'distance themselves from support for independence' (McNair, 2008: 239). In line with this, only the Sunday Herald openly positioned itself in favour of a Yes vote in the 2014 campaign. 


\section{Framing Campaigns}

Frames are schemata of interpretation we employ when we make sense of an event. Originating in the work of Goffman (1974), framing refers to ways in which an event is defined in our minds, which have implications for our expectations regarding the reasons, causes, effects and future outcomes of this event. In Goffman's terms, when experiencing an event we immediately impose a frame on it, which 'provide[s] a first answer to the question "what is going on here?"' (1974: 25).

For most events, several different frames may be applied and these frames compete in public discourse. Politicians, journalists and individuals use frames to understand and talk about public events and alternative frames promote different evaluations (Neuman et al., 1992: 60). They select and emphasise 'some aspects of a perceived reality and make them more salient in a communicating text, in such a way as to promote a particular problem definition, causal interpretation, moral evaluation and/or treatment recommendation' (Entman, 1993: 53).

Media frame analysis has been applied on the coverage of parliamentary elections in various countries (for example Mendelson, 1993; Cappella and Jamieson, 1997; Stromback and Dimitrova, 2006; Stromback and van Aelst, 2010; Pedersen, 2014) perhaps due to elections' centrality in the political life of nations. Despite differences in different national contexts, a frame which appears prominently in most of this empirical research is the strategic game frame. This describes coverage that views an election like a competition or strategic game between opponents. Evidence of this 
frame in media texts includes a focus on opponent sides winning or losing; war and games metaphors; analyses of candidates' performance, style and perception; and references to opinion polls as a measure of how opponents are doing (Cappella and Jamieson, 1997). Although generally seen in the literature as originating in the work of Jamieson (1992) and Cappella and Jamieson (1997) on the 'strategy' frame, frames that emphasise political strategy and 'game' metaphors were identified in other work around the same time (e.g. Patterson, 1993; Mendelsohn, 1993), and the strategic game frame has since been studied, tested and refined by a range of scholars (Lawrence, 2000; Stromback and Dimitrova, 2006; Stromback and van Aelst. 2010; Aalberg et al., 2012; Dunaway and Lawrence, 2015, among others).

The strategic game frame assigns roles to political actors and expectations about the outcome - the election is about opponents' tactics to win over voters, and the outcome is victory or defeat. The alternative to this politician-centric frame is to focus on policy areas (Aalberg et al., 2012). Lawrence (2000) refers to this as the 'issue' frame and its emphasis is on policy problems, politicians' proposals for their solution and their implications for the public.

Although, as suggested earlier, referendums are different from elections, two studies carried out in different contexts - Robinson's (1998) study of the 1995 Quebec independence referendum and de Vreese and Semetko's (2002, 2004a, 2004b) of the 2000 Danish referendum on the adoption of the Euro - also found prominent strategy and issue frames in media coverage. Studies of Swiss referendums on immigration found topic-specific frames (Gerth and Siegert, 2012), as well as generic contest frames (Hanggli and Kriesi, 2010). This poses a broader question on 
whether news output frames referendums differently from elections, or whether both are seen in similar terms.

\section{Methods}

This article examines how the Scottish independence referendum was framed in a range of Scottish newspapers at selected moments in the campaign. The sample includes the three Scottish indigenous daily morning titles which are marketed as Scottish national newspapers (the Scotsman, the Herald and the Daily Record), their Sunday sister papers (Scotland on Sunday, Sunday Herald and Sunday Mail), the two Scottish editions of English newspapers (the Scottish Sun and the Scottish Daily Mail) with the highest circulations at the time of the campaign (www.abc.org.uk) and their Sunday sisters (Scottish Sun on Sunday and Scottish Mail on Sunday). The papers were accessed in hard copy at the National Library of Scotland and all articles about the referendum in the selected weeks were included in the sample.

Although there are substantial differences in their circulation figures (the tabloids in the sample sell over 200,000 copies, while the broadsheets command a significantly lower 25-38,000), the ten titles had a combined Scottish circulation of $1,162,352$ at the end of the referendum campaign (www.abc.org.uk data for August 2014). This suggests that despite the dramatic readership decline, these titles still had a position in Scots' news consumption. Scottish indigenous newspapers are produced for a Scottish readership, while Scottish editions of English titles carry much of the content of their English editions, with some material replaced by regional news. 
The Scotsman and the Herald are broadsheets ('broadsheet' and 'tabloid' denote here type of content rather than paper size), and are associated with right-of-centre (the Scotsman) and left-of-centre (the Herald) positions (Hutchison, 2008). The Daily Record is a left-of-centre tabloid, traditionally supporting the Labour Party (McNair, 2008); the Scottish Sun is a right-of-centre tabloid (and since 2006 the highest-selling newspaper in Scotland), which has aligned itself with different parties in the past, including the SNP (Hutchison, 2008); and the Scottish Daily Mail is a Conservativesupporting, right-of-centre middle market title. The sample hence encompasses the entire spectrum of the daily morning and Sunday press in Scotland.

The article applies frame analysis on all the referendum coverage in these titles during seven weeks at different points in the two-year campaign. These weeks were selected to cover initiatives of both political campaigns (the launch of the SNP's White Paper and the meeting of the Westminster Cabinet in Aberdeen to discuss North Sea oil); the aftermath of the only election that took place during the referendum campaign; moments when the referendum would be expected to be topical because of their timing (one year before the vote, the week of the vote and the week of one of the two televised leader debates) and a week when nothing specific happened in the campaign.

- Week 1: 15.4.13 - 21.4.13; week early in the campaign when nothing specific happened

- Week 2: 16.9.13 - 22.9.13; a year before the referendum

- Week 3: 25.11.13 - 1.12.13; publication of SNP's White Paper 
- Week 4: 24.2.14 - 2.03.14; UK Cabinet in Scotland to discuss independence and North Sea oil

- Week 5: 26.5 .14 - 1.6.14; week after European Election, start of formal referendum campaign period

- $\quad$ Week 6: 4.8 .14 - 10.8.14; first televised referendum debate on 5.8

- $\quad$ Week 7: 14.9.14-20.9.14; referendum week

The rationale for selecting this sample was to cover as wide a period as possible and form a picture of the development of the coverage over time. Weeks covering campaign initiatives (3 and 4) may be logically expected to focus more on issues promoted by each side (two of these were included to maintain balance) and week 6 may be expected to focus on political leaders' competitive strategy, but no such assumptions could be made for the other weeks. A total of 3,415 articles was analysed in these seven weeks, with $55 \%$ of them found in the four broadsheet titles.

Through immersion in the sample, I identified alternative frames and measured their presence in the coverage ${ }^{1}$ using content analysis. The unit of analysis was the article and each unit was coded for presence of the different frames. When each frame is presented in the findings, I explain which indicators were used to decide its presence. One consequence of coding in this way was that individual articles included more than one frame. The advantage of this was that frames were not treated as mutually exclusive and could co-exist in the same narrative. Each frame was only recorded once in the same article. 
The frames identified could in principle be used by either side of the independence argument (as Nisbet (2010) suggests, the same frame can include pro, anti and neutral arguments), and it was not within the scope of the study to examine whether articles took a position in favour or against political sides. For instance, if a writer mentioned that a politician discussed how healthcare would be managed after the referendum and the writer then argued that the referendum was not about healthcare, but about British or Scottish identity, the article would be coded as carrying both the policy and identity frames. The article would be coded in the same way if the politician used the identity frame and the writer adopted the policy frame. All types of coverage were included (news, features, editorials, readers' letters and signed opinion articles, the latter also including articles by politicians, campaigners and members of the political commentariat) because coding focused on the themes that framed the debate rather than individual writers' points of view. That said, newspapers' positions in the political spectrum, as outlined earlier, are considered when discussing differences between titles in the prominence of different frames.

\section{The Referendum as a Strategic Game}

As explained in a previous section, the game frame presents campaigns as a game between opponent sides. It focuses attention on politicians' performance in the campaign, it emphasizes competition between those representing different parties and sees their ultimate goal as winning the contest. In measuring this frame, the following indicators were used: emphasis on the strategy of the Yes and No sides; use of war, game and horse-race language; emphasis on who is winning or losing; reports of how the two sides are doing in opinion polls; and analyses of politicians' performance. 
The representation of the referendum as a strategic game permeated the entire sample. In total, it was present in 1,803 articles (53\% of the total coverage) across the different papers, making it the most prominent frame overall.

For the first five of the seven weeks studied, the strategic game frame was the second most prominent frame and it was only in the last two weeks that it became the primary way of defining the referendum (figure 1). As discussed in the methods section, week 6 of the sample could be expected to involve a focus on campaign strategy and competition as it was the week of the first leaders' debate on television and a lot of the newspaper coverage assessed their performance. In the final week though, there was no similar campaign event. As the topicality of the referendum peaked that week, all the frames received increased attention, but the game frame was clearly dominant. In the week leading up to the vote, which is particularly important at the final stage of voters' decision-making process, newspapers presented the referendum primarily as a competition between two camps.

Figure 1 (prominence of frames per week).

It has been suggested that the use of the game frame in media coverage of campaigns generates cynicism among the electorate and encourages disengagement with politics (Cappella and Jamieson, 1997). This however was not the case in the Scottish referendum, which generated unprecedented levels of voter engagement this lends support to de Vreese and Semetko's (2002: 632) finding that the game frame does not influence voter turnout and mobilization. 
Perhaps then the significance of the prominence of the game frame lies in the aspects of the event that it excludes. By focusing readers' attention on strategy and competition between camps, it connects the decision with an evaluation of campaign performance. Robinson suggests that in general any news framing that focuses on opposition between political sides heightens polarization in a campaign (1998: 93) and directs voters' attention to oppositional style rather than substance (ibid: 102). Yet, as previously mentioned, the prominence of this frame is not unique to the Scottish case and has also been found in referendums in other contexts (Robinson, 1998; de Vreese and Semetko, 2002) - therefore it appears to be in line with a broader tendency in the framing of referendums.

\section{Policy Frames: Economy and Governance}

The other main way in which the referendum was framed was as a decision about policy areas. The indicators used to code the policy frame included reference to policy issues, the proposals of politicians and their impact for the public - therefore this frame corresponds to Lawrence's (2000) 'issue' frame. Two main categories of policy frames were identified: economic policy and policy relating to other areas, such as defence, membership of the EU and NATO, public services, welfare, immigration, broadcasting, etc. ${ }^{2}$ Like all the frames analysed here, the two categories of policy frame were not mutually exclusive and many articles contained both - besides decisions on governance are closely related to the economic resources available for investment. Economy and governance were treated as subcategories of the policy frame in the analysis (every article that contained one or both of them was also coded 
for the policy frame) and figure 1 above compares the prominence of the overarching policy frame in relation to the other frames in the coverage.

As figure 1 shows, the referendum was framed as being about policy for most of the campaign (in total the frame was present in 1,735 articles, or $51 \%$ of the total coverage), except for the final weeks. This shift of attention from policy to strategic game as the referendum approached may be due to the increased strategic efforts of the two sides, and to the predicted closeness of the outcome towards the end, which has generally been found to trigger the game frame in news coverage (Dunaway and Lawrence, 2015).

It appears so far that the two dominant frames in the coverage of the Scottish referendum, the game and policy frames, are the same ones that have been found in the coverage of election campaigns (Lawrence, 2000; Aalberg et al., 2012). Another feature that the coverage studied shares with that of elections is its strong focus on economic issues.

As mentioned, economy and governance aspects of the policy frame sometimes coexisted in articles, however looking at them separately reveals that particularly the economic consequences of the referendum were dominant in every week studied (figure 2). Overall they were present in 1,275 articles (37\% of the total coverage of the referendum and $73 \%$ of the articles categorized under the overarching policy frame) in the seven weeks of the sample.

Figure 2 (policy frame: economy versus governance) here. 
The economy frame sees the referendum as a decision about the financial future of Scotland. The referendum is presented as being about the wealth and prosperity of the country and about how the economy will be managed if it stays in the UK and if it becomes independent. It involves a focus on questions like the currency an independent Scotland would use, and how economic policy would impact businesses, investment, taxation, spending and jobs.

Research carried out in the context of election campaigns has also found the economy to be a key consideration. According to the 'economic voting' hypothesis, whether the economy is seen as going well plays an important role in voters' decision to re-elect a government (Sheafer, 2008) and the news media are a contributing factor in their evaluation of the economy (Soroka, 2006). As Bright et al. suggest in their discussion of the 1995 Quebec referendum, 'it is talk of the economy and not talk of the importance of culture and the need for social programs that is the primary medium of discussion in the political culture today' (1999:325). Obviously all the above research was carried out in diverse political and national contexts, which are in many ways different to the Scottish case, yet there seems to be a broader trend for political discourse during major political contests to focus on economic considerations, which transcends national boundaries.

The governance frame in figure 2 sees the referendum as being about policy consequences in areas such as public services, law and order, welfare, childcare, borders, defence, immigration, EU/Nato membership, sports, broadcasting, the role of the monarchy, etc. ${ }^{2}$ 
The only week when governance received equal attention to the economy was week $3(25 / 11-1 / 12 / 2013)$ of the sample, when the SNP's White Paper for independence was published (figure 2). The White Paper's own emphasis on governance and economic policy seems to be the reason for the prominence of this frame at that time. In the other weeks studied, the governance frame always lagged behind the economic one (overall it was present in 773 articles, or $23 \%$ of the total referendum coverage and $44 \%$ of the coverage of the overarching policy frame).

As the above observation suggests, the events of the campaign and the discourses promoted by politicians themselves played an important role in bringing policy to the attention of journalists. Although interviews with journalists would be needed to reveal the processes of frame-building and the influence of the frames promoted by the two campaigns, it is generally accepted that the media do not report on events in a vacuum and how they cover politics is the result of an interplay between journalists, politicians and their perceptions of what interests the public (Blumler and Gurevitch, 1995: 94-95).

Therefore the prominence of the policy frame in the referendum coverage - which may appear odd in this context considering that policy proposals are associated with party manifestos during elections - may be in part connected to the debates promoted by Yes and No campaigners. Another possible explanation may be offered by the argument that the constitutional issue in Scotland is actually about policy, and that disagreement with Westminster on areas like health, education or wealth distribution was what originally led to the questioning of constitutional structures (Paterson, 
2015). The prevalence of the 'pragmatic' (Castelló and Capdevila, 2013) policy frame in the coverage seems consistent with this view.

However, the question set on the ballot paper was not about policy but about whether Scotland should be independent, whether Scottish governments would have full control over all decision areas or would continue to share control with Westminster. This is a question broader than specific policy decisions, which depend on the proposals of election candidates, the outcomes of elections and the circumstances in which governments are required to legislate. Framing the referendum as being about policy logically promotes an expectation that specific policy outcomes would be delivered as a result of a No or a Yes vote, in the same way that one would expect policy outcomes to be delivered after an election.

Policy considerations were not a feature of newspaper discourse only: they also permeated opinion poll questionnaires, which asked respondents to rate the significance of different policy issues in relation to each other (TNS-BMRB, 2014a), again promoting the idea that the referendum decision was about policy. Results from these polls suggest that different policy areas figured in voters' decision-making, but further research with voters would be needed to clarify if they thought that the referendum was about policy and how this compared with other frames.

\section{Frames Specific to the Referendum}

All the other frames identified in the study were not common to other contexts and types of campaign, but specific to the Scottish referendum. These frames had 
marginal presence in the coverage during most of the weeks studied (figure 1). They received comparatively more mentions in the final week, when interest in the referendum peaked, but even then they were far behind the two dominant frames discussed so far.

These more marginal frames include the identity frame, whose indicators include references to Scottish distinctiveness or to the common features and history that Scots share with the rest of the UK. It tended to define national identity primarily in civic rather than ethnic terms (namely based on citizenship and shared values, rather than ancestry - see Billig et al., 2006), both when the identity referred to was Scottish and when it was British. This frame was found in a total of 254 articles in the seven weeks studied ( $7 \%$ of the coverage).

The self-determination frame presented the referendum as a choice on whether Scotland should make political decisions separately from the rest of the UK. Like identity, self-determination was also part of the political discourse in previous Scottish referendums (Jones, 1997) and in the coverage studied here it appeared in 207 articles (6\% of the coverage).

The divorce frame presented the relationship between England and Scotland as one of kinship and its ending as a divorce. In some instances of the frame, this divorce was difficult and undesirable, while in others it was presented as the resolution of a problematic relationship. It was found in 97 articles (3\% of the coverage), particularly towards the end of the campaign. 
According to the national division frame, the referendum was a cause of division in Scotland, whatever the outcome, because the issue of independence was highly conflictive. The frame was present in a total of 116 articles (3.4\% of the coverage), with 97 of these found in the final week of the vote, when opinion polls showed a closer split between Yes and No votes.

Finally, a frame which emerged exclusively in the final week (in 70 articles or $2 \%$ of the total coverage), and especially in the days directly before and after the vote, was the democratic achievement frame. This saw the referendum as a major achievement of the Scottish people, due to the high involvement of citizens in grassroots democracy and debate, the high turnout at the polls and the civility with which the referendum was carried out. Like the national division frame, this frame saw the referendum as having a deeper impact on Scottish public life irrespective of the outcome.

The frames in this section were not generic, like the game and policy frames, but specific to the referendum topic. They may be more widely characteristic of referendums on national separation, even though their presence in this coverage was relatively low.

\section{The Framing of the Referendum in Individual Papers}

The relative prominence of the frames in the different newspaper titles studied is very similar: as can be seen in table 1 below, the game and policy frames competed closely in most papers, each being present in around half of their coverage ${ }^{3}$. There are 
just a couple of exceptions to this pattern: in the daily and Sunday edition of the Scottish Sun and in the Sunday Mail (though not in the Daily Record) the game frame was dominant over the policy frame by a larger gap compared to the other newspapers. This seems broadly in line with research indicating that contest frames are more common in tabloid than broadsheet newspapers (Gerth and Siegert, 2012). On the other hand, the Scotsman and its Sunday sister Scotland on Sunday were the only titles where the policy frame was overall more prominent than the game frame.

Table 1 (distribution of frames: \% of overall coverage per newspaper) here.

In general though, different frames received similar degrees of attention between the different titles, which indicates that the framing of the referendum was very homogeneous across the press. A newspaper's position in the debate did not seem to make any difference in how it framed the referendum: the Sunday Herald was the only openly pro-independence title, yet like other papers it had a close balance between policy and game frames, a prominence of the economy over governance, and no significant difference from the more sceptical titles in the balance between the other frames. The arguments it provided may have been different from those found in other titles (a more detailed qualitative analysis would be required to explore this), but the Sunday Herald did not challenge the overall consensus that the referendum was about economic policy and competition between the two campaign sides. The relatively high presence of the self-determination frame in the Sunday Herald compared to its daily sister the Herald does not make it distinctive overall, as it was also found in other Sunday titles (Sunday Mail and Scottish Sun on Sunday) which, like the Herald, did not support independence. 
The homogeneity in the framing of the event across different titles may be attributed to a number of factors. On one hand, the prominence of the game frame has been seen as a wider feature of commercially oriented outlets (Stromback and van Aelst, 2010; Pedersen, 2014) and has also been linked to journalistic objectivity techniques (Pedersen, 2014): journalists in commercial media tend to use this frame because it is seen as attracting readership and at the same time it appears to preserve a sense of journalistic independence allowing journalists to question politicians without being perceived as favouring their political opponents. On the other hand, the prominence of policy frames in the coverage may be partly due to the influence of the campaigns on the media, of the media on each other, and to the broader reproduction of political discourses across different parts of the public sphere.

\section{Conclusions}

Returning to the question set at the start of the article, the press coverage of the Scottish referendum studied here was mainly dominated by the same frames found in the coverage of election campaigns, namely the game and policy frames. Another similarity between the coverage of this referendum and that of election campaigns was the centrality of the economy in the news. The coverage of the referendum also generated some frames which could be characteristic of referendums dealing with national separation, but these received much less attention comparatively. Although elections and referendums are different in nature, the data analysed here do not demonstrate much difference in how they were framed. 
This does not mean that newspapers told their readers that the referendum was of equal importance to an ordinary election, nor that voters saw it this way. The referendum was hailed as a very significant, one-off decision in much of this coverage and words like 'historic', 'once in a generation', 'unique opportunity' often appeared in the narratives of the press ${ }^{4}$. The unprecedented engagement of ordinary citizens in grassroots campaigning, in public meetings, in informal discussion, and eventually in the vote itself is unquestionable and was widely reported by the press, with much of the content of the democratic achievement frame focusing on this discourse.

This historic event, though, was framed by the press in much the same terms as other political contests. It was represented as a competition between two sides, especially at the end of the campaign, which may have been exciting and drawn more readers into the 'horserace', as the game frame might be expected to (Aalberg et al., 2012), but it also overemphasized the role of communication style in a decision that would outlive the two campaigns, their leaders and their strategies. Although the focus of this study was on the press, research on social media suggests that online debate also commented on the two campaigns, their strategies, and their performance, and was fired up by key events in the political campaign (Shephard, 2014). The press was just one platform in a dynamic reproduction and circulation of discourses in a wider public sphere (Garton et al., 1991).

The strategic game and policy frames were interweaved in much of the coverage. Framing the referendum as having concrete policy outcomes and the two sides as opponents may not have misled voters into thinking that the referendum was an election (because its uniqueness and historic significance were emphasized), but it 
still placed the decision-making process within an electoral cognitive framework and promoted a particular line of action (Entman, 1993) in making a decision: like in an election, voters would need to study policy proposals, evaluate them based on facts and decide which side they wanted to opt for.

There was an overall sense during the campaign though that it was not easy to gain 'knowledge' that would enable a decision on the referendum, and this was also reflected in opinion polling (TNS-BMRB, 2014b). One reason may be that facts and figures were interpreted differently by each campaign and were hard to evaluate; another may be that the direct result of the referendum would not be specific policy outcomes but an independent state or a devolved nation which would then need to make further decisions in elections and negotiations to achieve policy outcomes.

Frames that emerged more marginally in the press, like self-determination, or divorce, or other potential frames focusing on constitutional change, may have reflected more directly what was on the ballot paper, if they had been more prominent. Such frames, though, would have clashed with a Western journalistic tradition that generally sees referendums as political competitions and the economy as a key consideration in any political decision - as discussed, research on other referendums also found dominant game and policy frames (Robinson, 1998; de Vreese and Semetko, 2004a). They might also have seemed counter-intuitive by a viewpoint that suggests that the referendum 'was about constitutions only as constitutions ever have been contemplated in Scotland, as means to certain [...] policy ends' (Paterson, 2015: 43). The press framing of the referendum examined here supported such an understanding of the event and reinforced an expectation that 
Scotland's future in the UK will depend on policy decisions North and South of the Scottish border, and on the success of political campaigns in winning public support.

\section{Notes}

${ }^{1}$ With Yes/No questions answered for each article, e.g. 'does the article discuss politicians' performance?' or 'does the article use language associated with war or games?' for the strategic game frame.

2 The governance frame sees the referendum as a decision on how policy areas (other than the economy) should work. Although several areas were discussed in this frame, four were the most prominent: membership of the EU/Nato; borders and defence; public services; and welfare.

${ }^{3}$ As mentioned earlier, each article was coded for multiple frames, if more than one were present, and therefore figures do not add up to $100 \%$.

${ }^{4}$ At the time of the campaign, both sides excluded the possibility of a second referendum for a generation, although in June 2015 the SNP revised its position on this. 


\section{References.}

Aalberg T, Strömbäck J and de Vreese C (2012) The framing of politics as strategy and game: a review of concepts, operationalizations and key findings. Journalism: Theory, Practice and Criticism 13(2): 162-178.

Anderson B (1983) Imagined Communities: Reflections on the Origin and Spread of Nationalism. London: Verso.

Balibar E (1991) The nation form. In: Balibar E and Wallerstein I (eds) Race, Nation, Class: Ambiguous Identities. London: Verso.

Barford V (2014, 19 September) Scotland votes 'No': how the 'No' side won the referendum. BBC News. Available at http://www.bbc.co.uk/news/uk-29223984.

Billig M, Downey J, Richardson J, Deacon D and Golding P (2006) 'Britishness' in the Last Three General Elections: from Ethnic to Civic Nationalism. Report for the Commission for Racial Equality. Loughborough Centre for Communication Research. Loughborough: Loughborough University.

Blumler JG and Gurevitch M (1995) The Crisis of Public Communication. London: Routledge.

Bright R, Coburn E, Faye J, Gafijczuk D, Hollander K, Jung J and Syrmbos H (1999) Mainstream and marginal newspaper coverage of the 1995 Quebec referendum: an 
inquiry into the functioning of the Canadian public sphere. CRSNRCSA 36(3): 313330.

Cappella JN and Jamieson KH (1997) Spiral of Cynicism: The Press and the Public Good. New York: Oxford University Press.

Castelló E and Capdevila A (2013) Defining pragmatic and symbolic frames: newspapers about the independence during the Scottish and Catalan elections. Estudios sobre el Mensaje Periodístico 19 (2): 979-999.

Connell L (2003) The Scottishness of the Scottish press: 1918-39. Media, Culture \& Society 25(2): 187-207.

Curtice J (2014, 18 February) So where does Scotland stand on more devolution? Scotcen report available at: http://www.scotcen.org.uk/blog/what-does-scotlandthink-about-more-devolution.

Dardanelli P (2005) Democratic deficit or the Europeanisation of secession?

Explaining the devolution referendums in Scotland. Political Studies 53: 320-342.

Dekavalla, M. (2015) The Scottish newspaper industry in the digital era. Media, Culture and Society 37(1): 107-114.

Denver D (2002) Voting in the 1997 Scottish and Welsh devolution referendums: information, interests and opinions. European Journal of Political Research 41: 827843.

Devine T (1999) The Scottish Nation: 1700-2000. London: Penguin. 
De Vreese C and Semetko H (2002) Cynical and engaged: strategic campaign coverage, public opinion, and mobilization in a referendum. Communication Research 29(6): 615-641.

De Vreese C and Semetko H (2004a) Political Campaigning in Referendums: Framing the Referendum Issue. Abingdon: Routledge.

De Vreese C and Semetko H (2004b) News matters: influences on the vote in the Danish 2000 Euro referendum campaign. European Journal of Political Research, 43, 699-722.

Dunaway, J and Lawrence, R (2015) What predicts the game frame? Media ownership, electoral context, and campaign news. Political Communication 32 (1): 43-60.

Entman R (1993) Framing: toward clarification of a fractured paradigm. Journal of Communication 43(4): 51-58.

Garton, G, Montgomery, M and Tolson, A (1991) Ideology, scripts and metaphors in the public sphere of a general election. In: Scannell, P (ed) Broadcast Talk. London: Sage.

Gerth M and Siegert G (2012) Patterns of consistence and constriction: how news media frame the coverage of direct democratic campaigns. American Behavioral Scientist 56(3): 279-299. 
Goffman E (1974) Frame Analysis: An Essay on the Organisation of Experience. New York: Harper Colophon.

Guibernau M and Goldblatt D (2000) Identity and nation. In: Woodward K (ed) Questioning Identity: Gender, Class, Nation. London: Routledge.

Hanggli R and Kriesi H (2010) Political framing strategies and their impact on media framing in a Swiss direct-democratic campaign. Political Communication 27 (2): 141157.

Hutchison D (2008) The history of the press. In: Blain N and Hutchison D (eds) The Media in Scotland. Edinburgh: Edinburgh University Press, 55-70.

Jamieson KH (1992) Dirty Politics._New York: Oxford University Press.

Jones P (1997) A start to a new song: the 1997 devolution referendum campaign. Scottish Affairs 21: 1-16.

Kumar K (2003) The Making of English National Identity. Cambridge: Cambridge University Press.

Law A (2015) Mediating the Scottish independence debate. Media Education Journal 56: $3-7$. 
Lawrence R (2000) Game-framing the issues: tracking the strategy frame in public policy news. Political Communication 17: 93-114.

LeDuc L (2002) Referendums and elections: how do campaigns differ? In: Farrell D and Schmitt-Beck R (eds) Do Political Campaigns Matter? Campaign Effects in Elections and Referendums. London: Routledge.

McCrone D (2001) Understanding Scotland: the Sociology of a Nation. Second edition. London: Routledge.

McNair B (2008) The Scottish media and politics. In: Blain N and Hutchison D (eds) The Media in Scotland. Edinburgh: Edinburgh University Press, 227-242.

Mendelsohn M (1993) Television's Frames in the 1988 Canadian Election. Canadian Journal of Communication 18(2): 149-71.

Nairn T (1977) The Break-Up of Britain. London: Verso.

Neuman RW, Just MR and Crigler AN (1992) Common Knowledge. Chicago: University of Chicago Press.

Nisbet M (2010) Knowledge into action: framing the debates over climate change and poverty. In: D’Angelo P and Kuypers J (eds) Doing News Framing Analysis: Empirical and Theoretical Perspectives. New York: Routledge. 
Paterson L (2015) Utopian pragmatism: Scotland's choice. Scottish Affairs 24(1): $22-$ 46.

Patterson TE (1980) The role of the mass media in presidential campaigns: the lessons of the 1976 election. Social Science Research Council 34(2): 24-30.

Patterson TE (1993) Out of Order. New York: Knopf.

Pedersen R (2014) News media framing of negative campaigning. Mass Communication and Society 17(6): 898-919.

Robinson G (1998) Constructing the Quebec Referendum: French and English Media Voices. Toronto: University of Toronto Press.

Schlesinger P (1998) Scottish devolution and the media. In: Seaton J (ed) Politics and the Media: Harlots and Prerogatives at the Turn of the Millennium. Oxford: Blackwell.

Schlesinger P, Miller D and Dinan W (2001) Open Scotland? Journalists, Spin Doctors and Lobbyists. Edinburgh: Polygon.

Schudson M (2011) The Sociology of News. $2^{\text {nd }}$ Edition. New York: W.W.Norton.

Sheafer T (2008) The media and economic voting. International Journal of Public Opinion Research 20(1): 33-51.

Shephard M (2014, 16 September) Is the 'Yes' online tsunami finally paying 
dividends? Available at http://blog.whatscotlandthinks.org/2014/09/yes-onlinetsunami-finally-paying-dividends/.

Smith M (1994) Paper Lions: The Scottish Press and National Identity._Edinburgh: Polygon.

Soroka S (2006) Good news and bad news: asymmetric responses to economic information. Journal of Politics 68(2): 372-385.

Stromback J and Dimitrova D (2006) Political and media systems matter: a comparison of election news coverage in Sweden and the United States. International Journal of Press/Politics 11: 131-147.

Stromback J and van Aelst P (2010) Exploring some antecedents of the media's framing of election news: a comparison of Swedish and Belgian election news. International Journal of Press/Politics 15: 41-59.

TNS-BMRB (2014a) Which issue is most important to you in deciding how to vote in the referendum? Survey findings available at http://whatscotlandthinks.org/questions/which-issue-is-most-important-to-you-indeciding-how-to-vote-in-the-referendum.

TNS-BMRB (2014b) To what extent do you feel that you have enough knowledge to decide how to vote in the referendum? Survey findings available at http://whatscotlandthinks.org/questions/to-what-extent-do-you-feel-that-you-haveenough-knowledge-to-decide-how-to-vote\#line. 
Wettstein M (2012) Frame adoption in referendum campaigns: the effect of news coverage on the public salience of issue interpretations. American Behavioural Scientist 56(3): 318-333. 
Figure 1. Prominence of frames per week (number of articles)

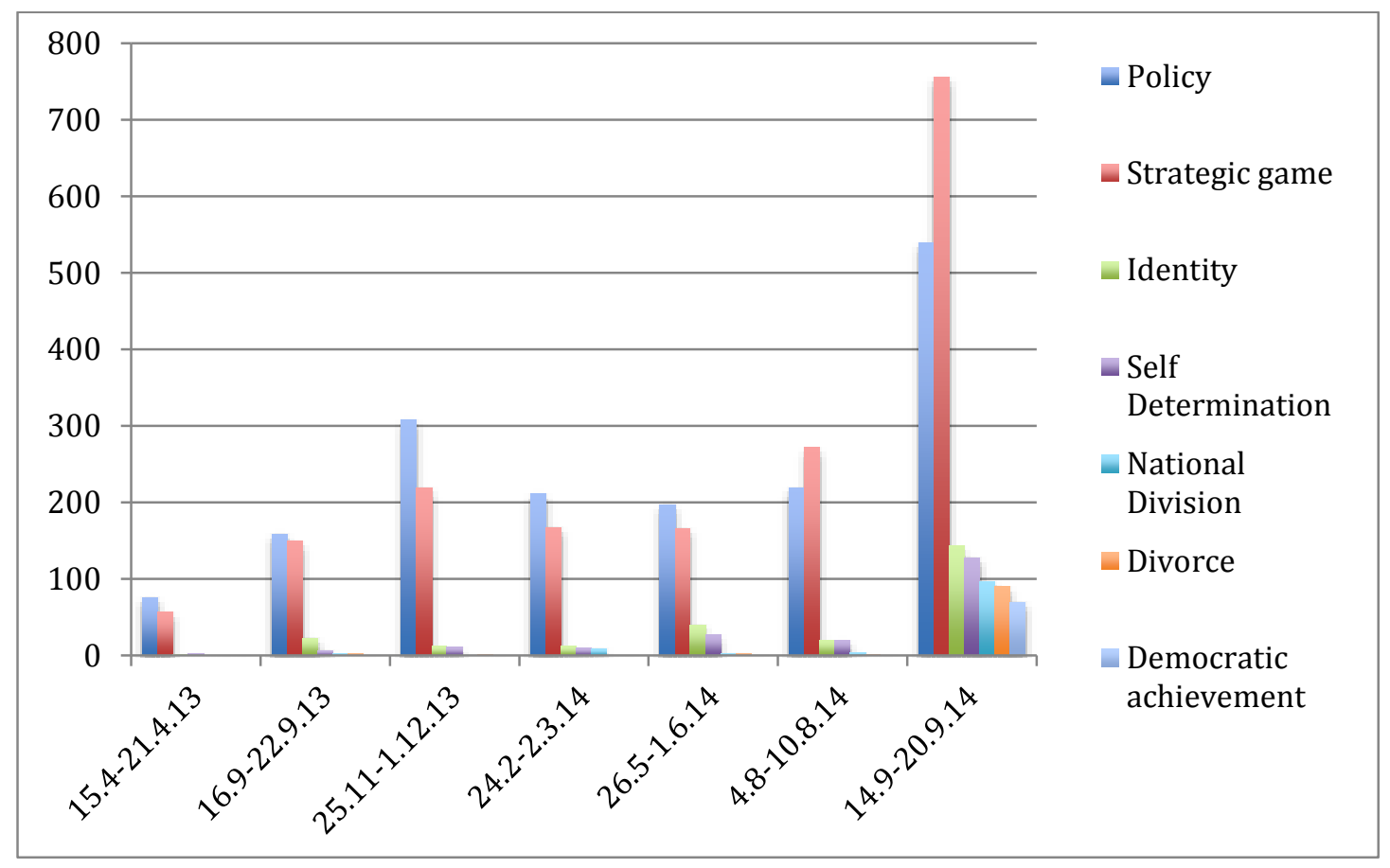


Figure 2. Policy frame: economy versus governance

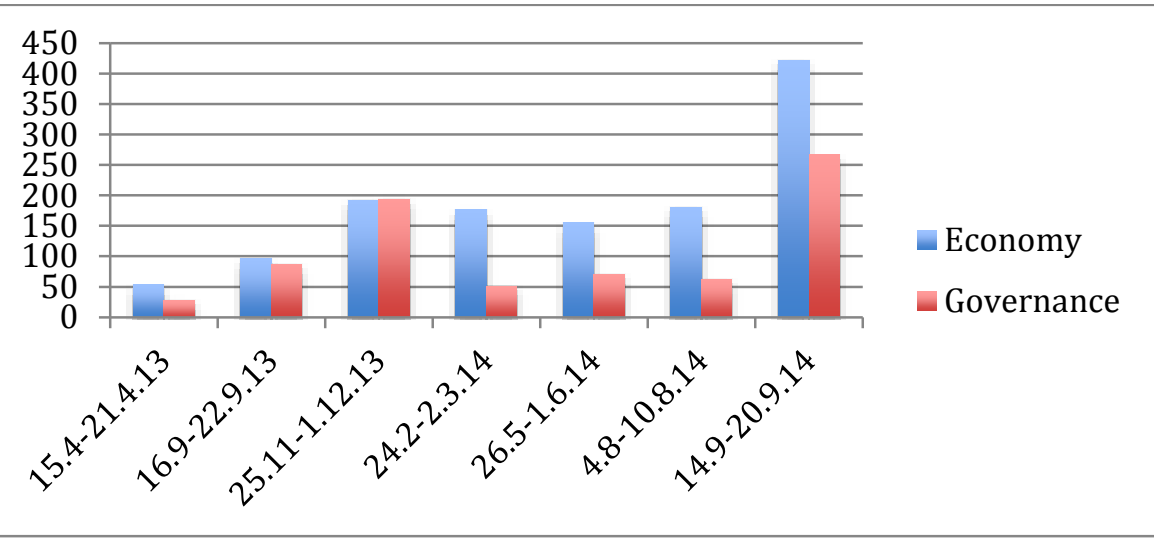


Table 1. Distribution of frames: \% of overall referendum coverage per newspaper

\begin{tabular}{|c|c|c|c|c|c|c|c|c|c|}
\hline & Economy & Governance & $\begin{array}{l}\text { Total } \\
\text { Policy } \\
\end{array}$ & $\begin{array}{l}\text { Strategic } \\
\text { game }\end{array}$ & Identity & Divorce/family & $\begin{array}{l}\text { Democratic } \\
\text { achievement }\end{array}$ & $\begin{array}{l}\text { Self } \\
\text { Determination }\end{array}$ & $\begin{array}{l}\text { National } \\
\text { Division } \\
\end{array}$ \\
\hline Scotsman & 37.7 & 22.4 & 54.3 & 43.8 & 8.3 & 1.4 & 0.6 & 6.5 & 3.5 \\
\hline Herald & 35.6 & 24.3 & 50.8 & 53.8 & 5.1 & 2.6 & 3.2 & 4.5 & 2.4 \\
\hline $\begin{array}{l}\text { Daily } \\
\text { Record }\end{array}$ & 36.3 & 22.2 & 47.6 & 51.1 & 5.8 & 3 & 3.2 & 7 & 3.4 \\
\hline $\begin{array}{l}\text { Scottish } \\
\text { Sun }\end{array}$ & 29.2 & 16.7 & 39 & 65.4 & 6.5 & 2.9 & 2.3 & 6.5 & 2.9 \\
\hline $\begin{array}{l}\text { Scottish } \\
\text { Daily } \\
\text { Mail } \\
\end{array}$ & 40.3 & 23.1 & 52.2 & 57.3 & 11.9 & 5.1 & 1.7 & 4.2 & 6.6 \\
\hline $\begin{array}{l}\text { Scotland } \\
\text { on } \\
\text { Sunday }\end{array}$ & 64.7 & 25.5 & 75.5 & 50 & 8.8 & 0 & 0 & 6.8 & 1.9 \\
\hline $\begin{array}{l}\text { Sunday } \\
\text { Herald }\end{array}$ & 43.7 & 25.2 & 56.3 & 55.5 & 6.7 & 2.5 & 3.4 & 10.1 & 0.8 \\
\hline $\begin{array}{l}\text { Sunday } \\
\text { Mail }\end{array}$ & 32.9 & 21.9 & 42.7 & 57.3 & 4.9 & 0 & 2.4 & 11 & 1.2 \\
\hline $\begin{array}{l}\text { Scottish } \\
\text { Sun on } \\
\text { Sunday }\end{array}$ & 38.5 & 15.4 & 48.7 & 56.4 & 15.4 & 0 & 0 & 10.2 & 5.1 \\
\hline $\begin{array}{l}\text { Scottish } \\
\text { Mail on } \\
\text { Sunday }\end{array}$ & 38.5 & 16.9 & 50.6 & 51.8 & 8.4 & 4.8 & 0 & 6 & 3.6 \\
\hline
\end{tabular}

